\title{
SEED HEALTH EVALUATION IN THE PROCESS OF FREE-VIRUS CITRUS SEED PRODUCTION ON KAMPAR REGENCY, RIAU PROVINCE OF INDONESIA
}

\author{
Dwiastuti M.E. ${ }^{*}$, Wuryantini S., Sugiyatno A., Supriyanto A. \\ Indonesia Citrus and Subtropical Fruit Research Institute, Indonesia \\ *E-mail: mutiaed@gmail.com
}

\begin{abstract}
Kampar is one of the largest citrus seed production centers in Indonesia which has a wide distribution range. In anticipating and preventing the spread of dangerous systemic diseases and the presence of vector pests, a survey was conducted to evaluate the health of the seeds and the application of technology to the process of citrus production in Kampar, Riau, Indonesia. The survey was conducted in November 2014 in Sungai Pinang, Tambang, Kampar Regency and at Padang Marpoyan Seed Center, Riau, Indonesia. The sample was selected by random sampling method on scattered seeds in captivity, Foundation Block (FB), Budwood Multiplication Block (BMB) plant in the protected screen house and in farmer land. The results of the survey showed that seed growers that have not used patches from the BMB mother tree are already available on the farmer's land of 1200 stems since 2014 while $\mathrm{BMB}$ in $\mathrm{BBI}$ is available since 2012. The condition of the parent FB and BMB trees managed by the Agriculture Service in Padang Marpoyan Seed Center is sufficiently good and protected in a screen house. The results of the seed health examination showed that the FB and BMB plants were free from Huanglongbing (HLB) and Citrus Tristeza Virus (CTV) diseases. Whereas, the field of BMB plants on the farmer's land with no screen house protection and Parent Tree showed that the plant's population in the field were infected with CTV by $66.7 \%$. The seed plants spread to $100 \%$ small seed grower were infected with CTV. In the medium seed grower cluster, CTV infection occurred as much as $87.5 \%$. In large seed grower, the indexing results showed a positive mark and contained Liberibacter asiaticum pathogens that cause HLB.
\end{abstract}

\section{KEY WORDS}

Evaluation, citrus free virus, seed production, Kampar.

The horticultural seedling sector in Indonesia still not fully ready to support the highly competitive products in the free trading industry such as China ASEAN Free Trade Area (CAFTA) and AFTA (ASEAN Free Trade Area). In citrus commodities, this happens because the seeding process still does not follow the flow of disease-free seed production. Whereas, since the outbreak of Huanglongbing (HLB) disease in the 1980s which is also known as Citrus Vein Phloem Degeneration (CVPD) caused by Liberibacter asiaticum (Bove, et al. 2000; Jagoueix et al., 1994; Jagoueix et al., 1996; Jagoueix et al. 1997; Subandiyah et al., 2000), there have been a decrease in the productivity of citrus for around 10 tons/ha. Until now, it has significantly damaged the citrus agribusiness in Indonesia. This disease is transmitted by the Diaphorina citri Kuw insect vector and propagation materials (seeds and patches).

Although the prospect of the citrus industry seems to be down because of the widespread effects of malignant diseases, citrus farmers still want to continue planting citrus because they assume that citrus is economically more beneficial compared to other food crops. The efforts to inhibit the spread of systemic diseases in the past have not been quite a success. The disease is still found in citrus plants over the age of 2 years. To overcome this issue, the Indonesian Citrus Rehabilitation Program has initiated a virus-free citrus seed production through Shoot Tip Grafting (STG) technology in in-vitro and indexing (Supriyanto \& Whittle, 1992; Supriyanto et al. 1992; Devy et al. 2015). In 1992, this program was successfully produced. The program distributed CVPD-free citrus seeds and other viruses in several production centers especially in North Bali. The success of the program was further 
strengthened by the Indonesian citrus certification program. The disease-free citrus seedling system was then become a recommendation and referred nationally by the Directorate of Horticulture Seedling with a legal support from the Decree of Minister of Agriculture number 39/Permentan/OT.140/8/2006 concerning the Production, Certification, and Distribution of Seed Regulations for disease-free citrus seeds. By that, in the production process and distribution of disease-free citrus seeds in Indonesia, the concerning parties must refer to this regulation. Thus far, the mother seed of disease-free citrus (Foundation Block (FB) has been spread in 29 provinces and has the status of Patches Block on Budwood Multiplication Block (BMB) in 34 Provinces (Supriyanto et al., 2017)

In citrus plants, the superior seeds are those which are free from systemic pathogens (HLB = Huanglungbin, CTV = Citrus Tristeza Virus, CVEV = Citrus Vein Enation Virus; CEV = Citrus Exocortis viroid, CPsV = Citrus Psorosis citrus) that are in accordance with the parent tree with guaranteed purity of variety. This seed can only be obtained if the parent tree is produced in accordance with national seed regulation. As for citrus seed production, it must be in accordance with the disease-free citrus production flow that has been produced by Balitjestro with the classification of basic seed (FB) and main seed (BMB). During the production process from FB, FB, and scattered seeds, there must be a periodic supervision and inspection from the Seed Monitoring and Certification Agency (Balai Pengawasan and Sertifikasi Benih or BPSB). The examined seeds that are still healthy and free of disease will be labeled as disease-free according to their status. FB seeds will be labeled in purple, BMB seeds will be labeled in pink, and scattered seeds will be labeled in blue.

Unfortunately, this good regulation has not been implemented fully by the community as reported in several Indonesian seed centers, such as in NTT (Supriyanto et al. 2015a). It was found that around $80-90 \%$ of citrus seeds were produced by two seeds factories which are Purworejo-Jateng and Kampar-Riau with a capacity of 1,500,000-2,000,000 citrus seeds per year. Those seeds are not labeled and have spread to a minimum of 7 provinces in Indonesia (Supriyanto et al., 2015b). The problem of unlabeled seed distribution has caused the national citrus industry to continue to decline. The latest data released by the Data and Information Center of Ministry of Agriculture in 2014 showed that in 5 years (2008-2013), there is a decline in the citrus plantation area for about 7,000 hectares (from 60,190 hectares in 2009 to 53,517 hectares in 2013). One of the main reasons in this matter is the attack of systemic diseases, especially HLB and CTV, due to the use of unlabeled wild seeds. As reported by Hartung et al., 2010 and Hilf 2011, HLB or CVPD spread from seeds to seeds. For this reason, farmers are encouraged to be careful in choosing seeds. It is recommended that farmers should only select blue-labeled citrus seeds and not others. The Department of Agriculture and the local BPSB, as well as the Directorate General of Horticulture as policymakers and supervisors, must be more assertive in controlling and enforcing various project regulations as well as providing seeds for farmers. Instead of being the agents of disease dissemination, seed growers must be responsible for preventing the spread of dangerous systemic diseases such as CVPD and CTV. This must be taken seriously in every movement of citrus agribusiness development in the country.

The purpose of the observation was to evaluate the health status of the seeds in the disease-free citrus seed production process in the development center of disease-free (bluelabeled) citrus seedling area of Bangkinang, Riau Province as a provider of citrus seeds in Sumatra that is also expected to become the pilot breeder in Indonesia.

\section{MATERIALS AND METHODS OF RESEARCH}

The observations were conducted in November 2014 in Kampar Regency, Riau Province, Indonesia. The selection of the research sites was done intentionally (selected random sampling method) in a cluster based on several considerations, such as 1) The biggest seed production center in Sumatera, 2) Big exporter of citrus seeds with label and with no label, 3) The citrus seeds in the area are feared to be contaminated with HLB and other viruses, and 4) The seed growers are based on small, medium, and large growers. The smaller selection unit of research sites is in districts that are concentrated in Bangkinang 
District, the largest seed center in Kampar. The data collection was carried out by using interviews and direct observation approach on the visual symptoms of diseases in fields. The data collection and sample of infected plants (primary data) were directly taken from 3 random farmers. Meanwhile, the secondary data was collected through interviews by asking questions. The observations consisted of the seeding profiles at Kampar Riau, the symptoms of pests and diseases found, the plant growth, the sampling, as well as HLB and CTV disease analysis in laboratories. The selected samples were determined based on the criteria, scattered seeds, as well as the parent tree of BMB and FB. The sampling of scattered seeds and BMB was carried out in a composite (50-100 plants were taken randomly and considered as one sample) while the sampling of FB was performed individually.

The CTV testing protocol was done with direct DAS-ELISA and CTV antibody kit with Polynitrophenyl phosphate (PNP) substrate (Dwiastuti \& Triwiratno 1994). The HLB indexing protocol to detect bacterial DNA of $L$. asiaticus $16 S \mathrm{r}$ DNA in $1160 \mathrm{bp}$ amplified by PCR method was carried out by using a forward primer (CAC CGA AGA TAT GGA CAA CA) and reverse primer (GTG GTT GTT GTT TTT CTT CTG). The PCR cycle used was Step 1: $94^{\circ} \mathrm{C}$ in 3 minutes, Step $2: 94^{\circ} \mathrm{C}$ in 1 minute; $60^{\circ} \mathrm{C}$ in 1 minute; $72^{\circ} \mathrm{C}$ in 2 minutes (30 cycles), Step 3: $72^{\circ} \mathrm{C}$ in 10 minutes, and Step $4: 4^{\circ} \mathrm{C}$ for a cooling state. Both protocols are in accordance with the method developed by the Balitjestro Testing Laboratory accredited by ISO-IEC $17025 / 2005$. All samples tested in the laboratory were accompanied by positive controls and negative controls as a comparison of the test results.

\section{RESULTS AND DISCUSSION}

Kampar Regency with an area of approximately $1,128,928$ Ha or $12.26 \%$ of Riau Province is an area located between 01000'40 "North Latitude to 00027'00" South Latitude and 100028'30"- 101014'30" East Longitude. This region is divided into 21 districts and 245 villages. The borders of Kampar Regency are: The North is adjacent to Pekanbaru City and Siak Regency, the South is bordered by Kuantan Singingi Regency, the West is surrounded with Rokan Hulu Regency and West Sumatra Province, while the East is next to Pelalawan Regency and Siak Regency.

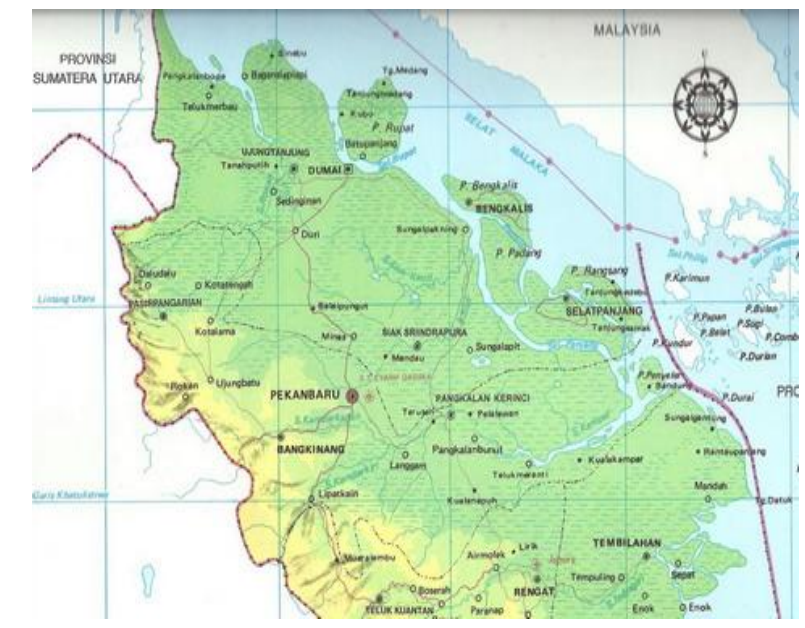

Figure 1 - Map of Riau Province

It is recorded that the population of Kampar Regency in 2010 was 687,797 people consisting of 354,434 male population (51.53 percent) and 333,363 female population (48.46 percent). The sex ratio (comparison of the male population with female population) is 106 . It is known that the most densely populated sub-district is Kampar District which is 327 people $/ \mathrm{Km}^{2}$ followed by Rumbio Jaya District which has 197 people $/ \mathrm{Km}^{2}$. In addition, there are other five districts which have a dense population namely Bangkinang District, North Kampar District, West Bangkinang District, Perhentian Raja District, and East Kampar 
District (each of which has 195 people $/ \mathrm{km}^{2}, 190$ people/ $/ \mathrm{Km}^{2}, 146$ people $/ \mathrm{Km}^{2}, 138$ people $/ \mathrm{Km}^{2}$ respectively). Meanwhile, the two relatively sparsely populated districts are Kampar Kiri Hulu District with 8 people $/ \mathrm{Km}^{2}$ and Kampar Kiri Hilir District with 13 people $/ \mathrm{Km}^{2}$.

The main commodities of Kampar Regency are plantation and services sector. The commodity of the plantation sector is rubber, oil palm, cocoa, coconut, and gambier (Anonymous, 2015).

The profile of citrus seedlings in Tambang Village, Tambang District, Kampar Regency. Tambang District and Sungai Pinang Village are the largest seed centers in Kampar District fulfilling $110 \mathrm{Ha}$ of Integrated Agricultural Technology Development Zone in Sungai Pinang Village that is funded by the Regional Budget in 2012. The citrus seed breeder in Tambang District consists of two groups: the citrus seed grower association and individual seed grower.

The number of association members is 27 growers which are divided into small growers (produce $<65,734$ plants), medium growers (produce 65,734-579,830 plants), and large growers (produce $>579,831$ plants). Supriyanto \& Sugiyatno 2015 wrote that of those 27 growers, there are 200 members or plasma growers which have a production capacity ranging from 2 to 3 million seeds per year. The seeds are mostly produced by using patches from their own trees which a small portion of it was processed by using the patches from BMB. However, not all of which are certified--this depends on the buyer. If the buyer is from the government agency, certification will be carried out, but if the buyer is an ordinary community, there will be no certification. Almost all growers use short polybags that is not in accordance with what has been recommended by the research results. This is due to the assumptions that small polybags are more economical in planting and transport.

There are 2-3 individual citrus seed growers which have large seed turnover. Besides cultivating citrus seeds, growers also seek other fruit seeds like durian, mangosteen, rambutan, matoa, longan, agarwood, and others. The source of the patches used is taken from their own large plants which have no certificate and short polybags.
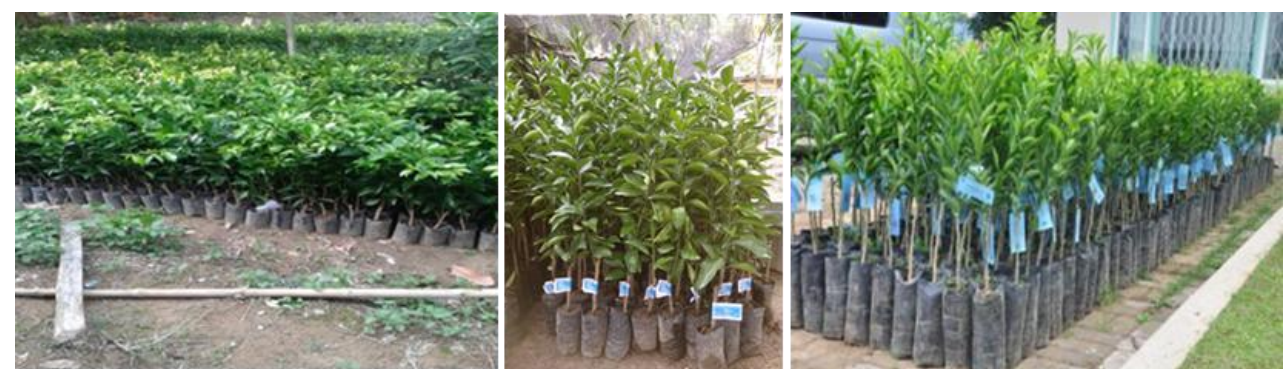

Figure 2 - Citrus seeds performance in Kampar (a) Most of the performance in Kampar is citrus seeds in short polybags and no labels; (b) The performance of blue-labeled (stickers) disease-free citrus seeds in Kampar with short polybags; (c) The performance of recommended free-disease citrus seeds in high polybags (3-liter volume) complete with a blue certification label

In both individual and association seed grower, the cultivated variety was $90 \%$ of Siam Madu seeds while the rest were lime and kaffir lime. All seed growers obtain seeds for the rootstock from Brastagi. The origin of the source of the patch is varied. Some of which come from fellow growers who have good field parent trees (PIP/PIT), some use their own parent trees in their fields, and some use the source from the BBI.

The availability of source seed for the patch:

- $\mathrm{BMB}$ in the screen house managed by Padang Marpoyan Seed Center is 1200 stems. The seeds which are worth to produce are 804 stems;

- There are 1200 stems of BMB with no screen house managed by 8 selected farmers and can produce 250,000 patches.

The results of the interview stated that the citrus seed production capacity in Kampar was $5,400,000$ per year. It is known that 192,240 of which were labeled while the others were not labeled and distributed to 10 provinces. The small implementation of seed labeling 
according to Purnomosidhi \& Roshetko 2012 is due to the long process of certification. There are an additional label and inspection fees which makes the selling price to be expensive. Viewed from the history of agricultural seed certification carried out since the early 1900s (Hackleman \& Scott, 1990), seed certification is an official labeling from the relevant agency which means that the labeled seed has gone through a process of health checks and purity, growth testing, and moisture content, as well as fulfilling all requirements to be duplicated or circulated (Mangold \& Bonner, 2008, Nyoka, et al. 2011; Falivene \& Creek 2017). For horticulture and plantation crops that the breeding process must go through a grafting process, there are two stages of certification process such as a) the certification of patches and b) the certification of finished seeds. The supervision procedure above is similar with other countries (Nyoka et al., 2011) so as to make high costs for the growers of horticulture.

Health evaluation of citrus seeds in Kampar. In general, citrus seeds are produced by seed growers either using random patches or using the patches from BMB which are relatively healthy and good. Nevertheless, there are still a number of non-lethal pests and diseases and nutrient efficiency found in the field. The pests that attack the plants are Toxoptera citricidus pest aphids, thrips sp., Phyllocnistis citrella peliang leaves caterpillar, infestation of scales on the leaves, and Bemisia sp whiteflies pest. On the other hand, the disease attacks are CVPD (Citrus Vein Phloem Degeneration), CTV (Citrus Tristeza Virus), leaves cancer (Xanthomonas anoxopodis pv. Citri), scabies (Spaceloma fadiuwcetti), greasy spots (Mycosphaerella citri), fungus soot (Capnodium citri), dead tips (Fusarium sp. + Alternaria sp), anthracnose branch necrosis (Colletotrichum sp.) (Table 1 and 2). The attack of pests and diseases is generally still controlled by atonic combined insecticides and fungicides except for CVPD and CTV (Dwiastuti et al. 2013, Dwiastuti 2016, David \& Gottwald 2014). The most common abiotic diseases are $\mathrm{Zn}$ and $\mathrm{Mg}$ nutrients. On average, 6 kinds of pest disturbances were found to be only $1.25-7.5 \%$ while the disease was small on a scale of $0.25-8.37 \%$.

Table 1 - The Citrus Seedling Pests in Sei Pinang Village, Tambang District, Kampar Regency, Riau Province

\begin{tabular}{|c|c|c|c|c|c|c|c|c|c|c|}
\hline \multirow{2}{*}{ Number } & \multirow{2}{*}{ Breeder / farmer group } & \multirow{2}{*}{ Plant status } & \multicolumn{8}{|c|}{ Pest Attack Incidence (\%) } \\
\hline & & & 1 & 2 & 3 & 4 & 5 & 6 & 7 & 8 \\
\hline \multicolumn{11}{|c|}{ Small Breeder < 65,734 seeds } \\
\hline 1 & Jumadil Khoirul & Scattered & 0 & 0 & 0 & 0 & 0 & 0 & 0 & 0 \\
\hline 2 & Raja M Nurdin & Scattered & 0 & 0 & 20 & 5 & 10 & 0 & 0 & 0 \\
\hline 3 & Joni & Scattered & 5 & 0 & 5 & 0 & 0 & 0 & 0 & 0 \\
\hline 4 & Muzar & Scattered & 5 & 0 & 0 & & 0 & 5 & 5 & 0 \\
\hline \multirow[t]{4}{*}{5} & Suseno & Scattered & & & & & & & & 0 \\
\hline & Syafrizal & Scattered & 0 & 0 & 0 & 5 & 0 & 0 & 0 & 0 \\
\hline & Syamsir & Scattered & 0 & 0 & 5 & 5 & 0 & 0 & 0 & 0 \\
\hline & Average & & 2.5 & 0 & 7.5 & 3.75 & 2.5 & 1.25 & 1.25 & 0 \\
\hline \multicolumn{11}{|c|}{ Medium breeder $65,734-579,830$ seeds } \\
\hline 6 & Afrizal & Scattered & 0 & 0 & 10 & 0 & 0 & 0 & 0 & 5 \\
\hline 7 & A.Nurohman & Scattered & 0 & 0 & 0 & 0 & 5 & 0 & 0 & 0 \\
\hline 8 & Idris & Scattered & 0 & 0 & 5 & 0 & 0 & 0 & 0 & 0 \\
\hline 9 & Nopianti & Scattered & 5 & 0 & 5 & 5 & 5 & 0 & 0 & 0 \\
\hline 10 & Astanti & Scattered & 0 & 0 & 5 & 5 & 0 & 0 & 0 & 0 \\
\hline \multirow[t]{2}{*}{11} & Baidarus & Scattered & 15 & 0 & 0 & 0 & 0 & 0 & 0 & 0 \\
\hline & Rismadiyanto & Scattered & 0 & 0 & 0 & 0 & 0 & 0 & 5 & 0 \\
\hline \multirow[t]{2}{*}{12} & Mohamad Bibit & Scattered & 0 & 0 & 5 & 0 & 0 & 3 & 7,5 & 0 \\
\hline & & & 5 & 0 & 6.25 & 1.25 & 2.5 & 0.75 & 3.13 & 1.25 \\
\hline \multicolumn{11}{|c|}{$\begin{array}{l}\text { Large Breeder } \\
>579,831 \text { seeds }\end{array}$} \\
\hline 13 & Anasrun & Scattered & 5 & 0 & 5 & 0 & 0 & 5 & 5 & 0 \\
\hline
\end{tabular}

Note:

1 Chocolate aphid (Toxoptera citricidus), black (Toxoptera Aurantii), green (Myzus persicae)

2 Orange fleas (Diaphorina citri)

3 Leaf Peliang (Phylocnistis citrella)

4 Trips (Scirtothrips citri)
5 Scales fleas (Aonidiella aurantii)

6 Mite (Panonychus citri Phyllocoptruta oleivora)

7 Dompolan fleas (Planococcus citri)

8 Whitefly 
Table 2 - The Incidence of Disease in Citrus Seeds growers without Blue Label in Sei Pinang Village, Tambang District, Kampar Regency, Riau Province

\begin{tabular}{|c|c|c|c|c|c|c|c|c|c|c|c|}
\hline \multirow{2}{*}{ No } & \multirow{2}{*}{ Seed growers /farmer group } & \multirow{2}{*}{ Plant Status } & \multicolumn{9}{|c|}{ Disease Attack Incidence (\%) } \\
\hline & & & 1 & 2 & 3 & 4 & 5 & 6 & 7 & 8 & 9 \\
\hline \multicolumn{12}{|c|}{ Small Breeder } \\
\hline 1 & Jumadil Khoirul & Scattered & 0 & 4 & 0 & 0 & 50 & 3 & 10 & 0 & 5 \\
\hline 2 & Raja M Nurdin & Scattered & 1 & 3 & 1 & 7.5 & 3 & 5 & 10 & 5 & 12.5 \\
\hline 3 & Joni & Scattered & 0 & 0 & 0 & 0 & 0 & 0 & 0 & 0 & 0 \\
\hline 4 & Muzar & Scattered & 0 & 0 & 0 & 0 & 0 & 0 & 0 & 5 & 5 \\
\hline \multirow[t]{2}{*}{5} & Suseno & Scattered & 0 & 0 & 0 & 4 & 10 & 0 & 5 & 0 & 5 \\
\hline & Rata2 & & 0.25 & 1.75 & 0.25 & 0.18 & 15.75 & 2 & 6.25 & 2.5 & 6.87 \\
\hline \multicolumn{12}{|c|}{$\begin{array}{l}\text { Medium Breeder } \\
65,734-579,830\end{array}$} \\
\hline 6 & Afrizal & Scattered & 1 & 2.5 & 1 & 6.3 & 0 & 0 & 0 & 0 & 3 \\
\hline 7 & A.Nurohman & Scattered & 1 & 6 & 0 & 37.5 & 20 & 0 & 0 & 0 & 12 \\
\hline 8 & Idris & Scattered & 0 & 3 & 63 & 0 & 13 & 31 & 0 & 0 & 16 \\
\hline 9 & Nopianti & Scattered & 0 & 12 & 5.6 & 0 & 11.5 & 0,9 & 5 & 0 & 46 \\
\hline 10 & Astanti & Scattered & 0 & 0 & 0 & 1 & 0 & 0 & 0 & 0 & 1 \\
\hline 11 & Rismadiyanto & Scattered & 0 & 0 & 5 & 25 & 5 & 35 & 0 & 0 & 20 \\
\hline 12 & Baidarus & sebar & 0 & 6 & 9.3 & 3 & 5 & 4.6 & 0 & 0 & 5 \\
\hline \multirow[t]{2}{*}{13} & Mohamad Benih & sebar & 2.5 & 4 & 3.3 & 0 & 0 & 5 & 0 & 0 & 5 \\
\hline & Rata2 & & 0.34 & 8.37 & 6.70 & 5.6 & 4.19 & 5.88 & 0.38 & 0 & 8.30 \\
\hline \multicolumn{12}{|c|}{$\begin{array}{l}\text { Large Breeder } \\
>579,831\end{array}$} \\
\hline 14 & Anasrun & Scattered & 0 & 0 & 0 & 0 & 0 & 0 & 0 & 5 & 5 \\
\hline
\end{tabular}

Note:

1 HLB /Huanglungbin (CVPD) Liberobacter asiaticum

6 Rotten anthracose leaves (Colletotrichum $s p$ )

2 CTV (Citrus Tristeza Virus)

3 Dead tips (Fusarium $s p+$ Alternaria $s p$ )

4 Scabies (Spaceloma fawcetti)

5 Citrus cancer (Xanthomonas anoxopodis)

7 Greasy spot (Mycosphaerella citri)

8 Fungus soot ( Capnodium citri)

9. Zn deficiency

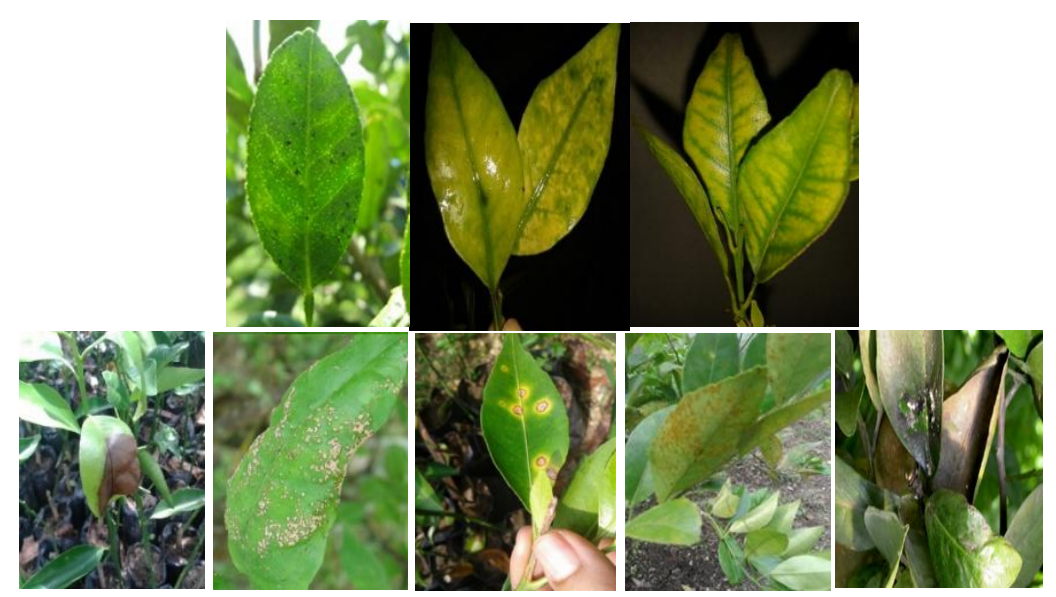

Figure 3 - The symptoms of the disease that attack citrus seeds in Sei Pinang Village, Tambak District, Kampar Regency are a). Vien clearing (Citrus Tristeza virus), b). Dead tips (Fusarium sp. +

Alternaria sp), c). Zn nutrient deficiency, d). Scabies (Spaceloma fawcetty), e). Leaf cancer (Xanthomonas anoxopodis pv. Citri), d). Greasy spot (Mycosphaerella citri), and e). fungus soot (Capnodium citri)

The breeder groups which produce the healthiest seeds are large seed growers. The symptoms of CTV disease in the form of a light vein clearing which will appear more clearly on lemon and lime are observed on 8 locations of captivity. Capnodium citri which is usually found in citrus plants in captivity or in other citrus centers is relatively rare here. This happens probably because the condition of the humidity around the plant is quite low, $\pm 62 \%$ with a temperature of $\pm 34^{\circ} \mathrm{C}$. This is not the ideal condition for the growth and development 
of this fungus. The dead tips that occur in some seed growers are thought to be caused by the splashing of rainwater or water that is contaminated by the pathogen fungus inoculum.

From the pests and diseases attack, the development of dangerous diseases that need to be taken into account is CTV and HLB disease. The spread of the disease is thought to occur through the use of infected entres. Dwiastuti et.al., 2013 believed that CTV disease is transmitted by aphids which can transmit the virus if it sucks the sick plant for 5 seconds with an incubation period of 5 seconds. CTV transmission can occur effectively if 27 aphids transmit the disease to healthy plants simultaneously. CVPD disease is transmitted by diaphorina citri insects or infected patches. Diaphorina citri insects can contaminate the healthy plants 160-360 hours after they eat the bacteria.

The production and distribution process of the disease-free citrus material multiplication should follow the regulations that have been recommended nationally such as the cleaning PIT of systemic pathogens especially CVPD/HLB, CTV CVEV, CEV and CPsV that its existence is found in Indonesian citrus plantation and distributed through the FB, BMB, and seed growers to be planted by farmers (Supriyanto et al. 1992).

The evaluation of seed health for systemic diseases in the process of citrus seed production in Kampar based on the Elisa test (Enzyme-Linked Immunosorbent Assay) and PCR (Polymerase Chain reaction). The search for citrus seed health against systemic diseases ranging from $\mathrm{FB}, \mathrm{BMB}$, seed growers to plants in the field with Elisa and PCR tests shows that:

The citrus mother plants in the field were used as a source of citrus seeding in Kampar Regency. The plants were infected with CTV by $66.7 \%$ but still free of CVPD. In small breeding clusters, $100 \%$ of the plants were infected with CTV while in medium breeding clusters; the CTV infection occurred as much as $87.5 \%$. On the other hand, there was an infection of CTV by $100 \%$ and CVPD by $50 \%$ in large seed growers. The tracing continued until the orange (3.5-year-old) planted in Topas palm oil plantation owned by Anasrun which had the symptoms of blotching and Zn deficiency is found. This shows that all samples have been contaminated with HLB and CTV (Table 3). In addition, electrophoresis results are presented in Figures 3 and 4 as the final process of PCR. This can be seen that the composite samples in large seed growers and field plants are infected with HLB.

From the above evaluation, it can be noted that there are three main problems faced by citrus seed growers in Bangkinang region such as technical, regulatory, and institutional problems. Those problems are interrelated with each other. What is meant by technical problems is the ignorance or inability of seed growers to adopt the recommended technology.
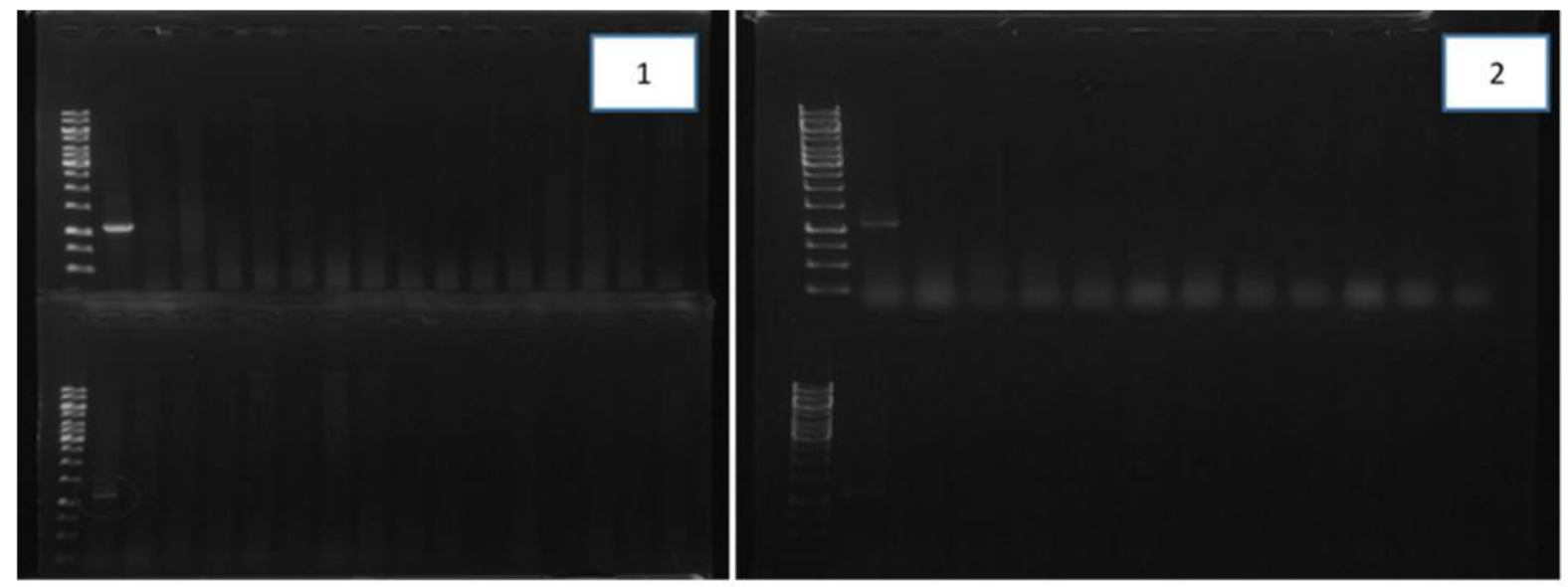

Figure 4(1) - Two electrophoresis gels resulted from DNA amplification of Liberobacter asiaticus causing HLB with a special primer on PCR test results. $L=K B$ leader; $P C=$ Positive control; $N C=$ negative control. Top gel: sample no. $1-14=$ scattered seed, bottom gel: sample number 15-28 = scattered seeds.

Figure 4(2) - Top gel: sample number 29-32 = scattered seeds, sample number 33-35 = field PIP, $36=$ scattered seed, $37-42=$ BMB without screen; Bottom gel: sample number 43 - $45=$ BMPT without screen, $46-48=$ BMB with screen. Nothing generates band (ribbon) in 1160 Kilo base, which means it contains Liberobacter asiaticus causing a CVPD, except on the positive control (next to KB leader). 

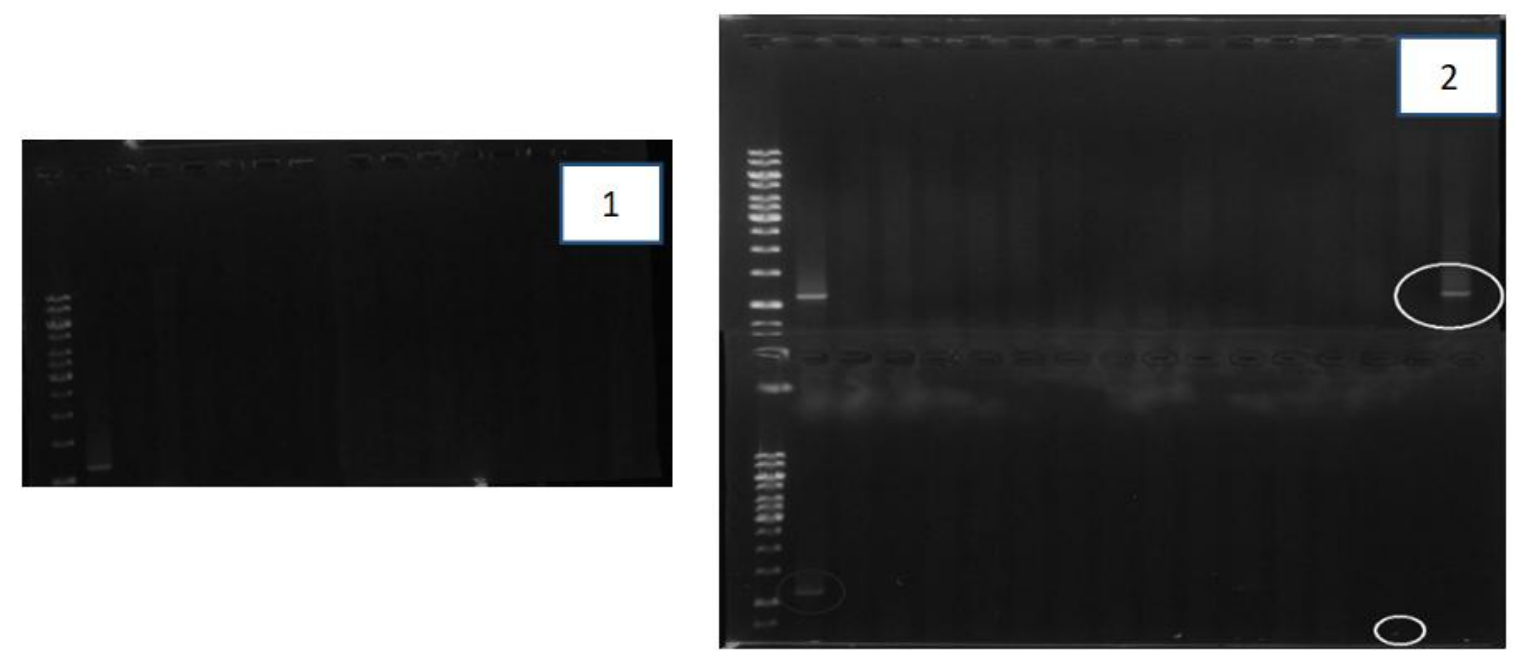

Figure 5(1) - Electrophoresis gel resulted from DNA amplification of Liberobacter asiaticus causing HLB with a special primer on PCR test results. $L=K B$ leader; $P C=$ Positive control; $N C=$ negative control. Samples number 49-50 = BMB screen, 51-61 $=$ FB screen.

Figure 5(2) - Two electrophoresis gels resulted from DNA amplification of Liberobacter asiaticus causing HLB with a special primer on PCR test results. $L=K B$ leader; $P C=$ Positive control; $N C=$ negative control. Top gel: sample number $63-65=F B$, 66 = scattered seeds, 67-69 field BMB, $70.71=$ scattered seeds, $72-74=$ field PIP, $75=$ scattered patches. Bottom gel: $76=$ scatter extracts. $77-79=$ BMB screen, $80-82=$ field PIP, 83-85 $=3.5$ productive plants. Samples number 75 and 84 produce bands (bands) at 1160 Kilo Base, which means that Liberobacter asiaticus is the cause of CVPD, as in the positive control (next to $\mathrm{KB}$ leader)

Table 3 - The observation of visual symptoms and HLB and CTV systemic disease indexing results (with ELISA and PCR techniques) in the Foundation Block parent tree, field BMB mother tree, screen house, and citrus population parent tree in Sei Pinang Village, Tambang District, Kampar Regency,

Riau Province

\begin{tabular}{|c|c|c|c|c|c|c|}
\hline \multirow[t]{2}{*}{ Number } & \multirow[t]{2}{*}{ Manager } & \multirow{2}{*}{$\begin{array}{l}\text { Parent Tree } \\
\text { Status }\end{array}$} & \multirow[t]{2}{*}{ Variety } & \multirow{2}{*}{$\begin{array}{c}\text { Number of Observed } \\
\text { Plants (tree) }\end{array}$} & \multicolumn{2}{|c|}{$\begin{array}{l}\text { Indexing } \\
\text { Results }\end{array}$} \\
\hline & & & & & CVPD & \\
\hline \multicolumn{7}{|c|}{ Mother tree in screen house } \\
\hline 1. & $\begin{array}{l}\text { BBI Padang } \\
\text { Marpoyan }\end{array}$ & $\begin{array}{l}\text { Foundation } \\
\text { Block }\end{array}$ & Siam honey & 8 individuals & - & - \\
\hline 2 & $\begin{array}{l}\text { BBI Padang } \\
\text { Marpoyan }\end{array}$ & $\begin{array}{l}\text { Foundation } \\
\text { Block }\end{array}$ & $\begin{array}{l}\text { Siam } \\
\text { pontianak }\end{array}$ & 7 individuals & & \\
\hline 3 & $\begin{array}{l}\text { BBI Padang } \\
\text { Marpoyan }\end{array}$ & BMB screen & Siam honey & Composites of 300 & - & - \\
\hline 4 & $\begin{array}{l}\text { BBI Padang } \\
\text { Marpoyan }\end{array}$ & $\begin{array}{l}\text { BMB screen } \\
\text { house }\end{array}$ & $\begin{array}{l}\text { Siam } \\
\text { pontianak }\end{array}$ & Composites of 300 & - & - \\
\hline 5 & $\begin{array}{l}\text { BBI Padang } \\
\text { Marpoyan }\end{array}$ & BMB screen & K Trigas & Composites of 300 & - & - \\
\hline 6 & Moh. Benih & BMB screen & siam & 4 Composites & - & - \\
\hline 7 & Muzak & BMB screen & siam & 3 Composites & - & - \\
\hline & Percentage & & & & $0 \%$ & $0 \%$ \\
\hline \multicolumn{7}{|c|}{ Field mother Tree } \\
\hline 8 & Astanti & BMB Field & siam & 3 composites of 200 & - & - \\
\hline 9 & Raja M Nurdin & BMB Field & siam & 4 composites of 200 & - & $\begin{array}{l}+ \\
(200)\end{array}$ \\
\hline 10 & Joni & BMB Field & siam & 3 composites of 200 & - & $\begin{array}{l}+ \\
(200)\end{array}$ \\
\hline 11 & Nurahman & PIP Field & siam & 3 individuals & - & $\begin{array}{l}+ \\
(3)\end{array}$ \\
\hline 12 & Baidarus & PIP Field & siam & 3 individuals & - & + \\
\hline 13 & Anasrun & PIP Field & siam & 3 individuals & - & $\begin{array}{l}+ \\
(3)\end{array}$ \\
\hline \multicolumn{4}{|c|}{$\begin{array}{l}\text { Percentage } \\
\text { Small seed growers }\end{array}$} & 609 plants & $0 \%$ & $66.7 \%$ \\
\hline 14 & Jumadil khoirul & $\begin{array}{l}\text { Scattered } \\
\text { Seeds }\end{array}$ & siam & 2 composites & - & + \\
\hline
\end{tabular}




\begin{tabular}{|c|c|c|c|c|c|c|}
\hline 15 & Joni & $\begin{array}{l}\text { Scattered } \\
\text { seeds }\end{array}$ & siam & 2 composites & - & + \\
\hline 16 & Raja & $\begin{array}{l}\text { Scattered } \\
\text { seeds }\end{array}$ & siam & 2 komposit & - & + \\
\hline 17 & Suseno & $\begin{array}{l}\text { Scattered } \\
\text { seeds }\end{array}$ & siam & 1 composites & - & + \\
\hline \multicolumn{7}{|c|}{ Medium seed growers } \\
\hline 18 & Afrizal & $\begin{array}{l}\text { Scattered } \\
\text { seeds }\end{array}$ & siam & 3 composites & - & + \\
\hline 19 & A.Nurohman & $\begin{array}{l}\text { Scattered } \\
\text { seeds }\end{array}$ & Siam, kaffir & 3 composites & - & - \\
\hline 20 & Idris & $\begin{array}{l}\text { Scattered } \\
\text { seeds }\end{array}$ & Siam & 2 composites & - & + \\
\hline 21 & Nopianti & $\begin{array}{l}\text { Scattered } \\
\text { seeds }\end{array}$ & $\begin{array}{l}\text { Siam, lime, } \\
\text { kaffir }\end{array}$ & 5 composites & - & + \\
\hline 22 & Astanti & $\begin{array}{l}\text { Scattered } \\
\text { seeds }\end{array}$ & Siam & 2 composites & - & + \\
\hline 23 & Rismadiyanto & $\begin{array}{l}\text { Scattered } \\
\text { seeds }\end{array}$ & $\begin{array}{l}\text { Siam, JC, } \\
\text { kaffir }\end{array}$ & 4 composites & - & $-/+$ \\
\hline 24 & Baidarus & $\begin{array}{l}\text { Scattered } \\
\text { seeds }\end{array}$ & Siam & 2 composites & - & + \\
\hline 25 & Mohamad Benih & $\begin{array}{l}\text { Scattered } \\
\text { seeds }\end{array}$ & siam & 2 composites & - & + \\
\hline & \multicolumn{5}{|c|}{ Large seed growers } & $87.5 \%$ \\
\hline 26 & Anasrun & $\begin{array}{l}\text { Scattered } \\
\text { seeds }\end{array}$ & Siam, JC & 7 composites & $-/+$ & + \\
\hline & $\begin{array}{l}\text { Percentage } \\
\text { ts }(3,5 \text { yo })\end{array}$ & & & & $50 \%$ & $100 \%$ \\
\hline 27 & Anasrun & Field plants & siam & composites & + & + \\
\hline & Percentage & & & & $100 \%$ & $100 \%$ \\
\hline
\end{tabular}

To overcome these problems and at the same time encourage seed industrialization in Bangkinang, the strategies presented by Supriyanto \& Sugiyatno 2015 are: (1) Technical, improving and enhancing the knowledge and ability of seed growers to produce good citrus seeds by conducting training, apprenticeship, and comparative studies on sites/institutions that are competent in producing disease-free citrus seeds; (2) Regulation, the regulation socialization of blue-labeled citrus seed production to citrus seed growers must be carried out frequently and followed by rigorous supervision and control from BPSB task forces during the production process; and (3) Institutional, strengthening the institutional seed growers which in this case is the association of fruit seed growers in Kampar regency. All parties must be able to increase the independence of the association to access the technology, funding, markets, and professionalism. Regular meetings still need to be done with fresh and useful material to build the association member together. Besides that, the role of local government in strengthening the breeding institutions is still very much needed.

\section{CONCLUSION}

Citrus seedlings in Kampar Riau have not been free from CVPD and CTV systemic disease infections in which it becomes a latent danger of harmful disease outbreaks. The labeling status and certification of citrus seeds in Kampar to evaluate the health of citrus seeds still has a small percentage. There are only $3.56 \%$ blue-labeled seeds from 54,000 citrus seeds production capacity with a range of distribution to 10 provinces in Indonesia. The process of health checks in certification is assumed to be long and might increase the production costs.

\section{REFERENCES}

1. Anonymous. 2015. Retrieved from https://id.wikipedia.org/wiki/Kabupaten_Kampar on September 9th, 2015. 
2. Bove J.M., Erti Dwiastuti M., Triviratno A., Supriyanto A., Nasli E., Becu P, Garnier M., $2000 \mathrm{~b}$. Incidence of huanglongbing and citrus rehabilitation in North Bali, Indonesia. Proceedings of 141f. Conference 10CV, IOCV, Riverside 2000, 200-206.

3. Hall, D.G. and Gottwald, T.R. 2014. Pest Management Practices Aimed at Curtailing Citrus Huanglongbing Disease.

4. Devy, N.F., Hardiyanto, and Dwiastuti, M.E. (2015). Teknologi Shoot-top Grafting and Indeksing, aplikasinya pada perbenihan jeruk bebas penyakit. IAARD PRESS, pp. 80.

5. Dwiastuti, ME \& A. Triwiratno. 1994. Indeksing CTV dengan metode DAS Elisa pada tanaman jeruk di BF and BPMT di Indonesia. Proceeding. Seminar Hasil and Pengembangan Bioteknologi II, Bogor, 1994: 1-8

6. Dwiastuti, M.E, Triwiratno, A., Endarto, O., Wuryantini S., \& Yunimar. 2013. Buku Panduan Teknis. Pengenalan and Pengendalian Hama and Penyakit Tanaman Jeruk. Balai Penelitian Tanaman Jeruk and Buah Subtropika. Pusat Penelitian and Pengembangan Hortikultura. Badan Penelitian and Pengembangan Pertanian.

7. Dwiastuti, M.E. 2016. Mencegah Ancaman Penyakit Sistemik Jeruk: Bangkitkan Kejayaan Jeruk Lokal. IAARD PRESS, pp.77.

8. Haclemman J.C. and Scott W.O. 1990. A History of Seed Certification in The United State and Canada. Association of official Seed Certification Agencies. Raleigh

9. Hartung, J. S., Halbert, S.E., Pelz-Stelinski, K., Brlansky, R.H., Chen, C., \& Gmitter, F.G. 2010. Lack of evidence for transmission of 'Candidatus Liberibacter asiaticus' through citrus seed taken from affected fruit. Plant Disease 94(10):1200-1205.

10. Hilf, M. E. 2011. Colonization of citrus seed coats by 'Candidatus Liberibacter asiaticus': Implications for seed transmission of the bacterium. Phytopathology 101:1242-1250.

11. Jagoueix S., Bove J.M., Garnier M., 1994. The phloem-limited bacterium of greening disease of citrus is a member of the a. subdivision of the P1'Oteobacteria. International Journal of Systematic Bacteriology 44: 397-386.

12. Jagoueix S. 1996. PCR detection of the two 'Candidatus' liberobacter species associated with greening disease of citrus. Molecular Cellular Probes 10: 43-50.

13. Jagoueix S., Bove J.M., Garnier M., 1997. Comparison of the 16S/23S Ribosomal Intergenic Regions of "Candidatus Liberobacter asiaticus" and "Candidatus Liberobacter africanum", the two species associated with Citrus Huanglongbing (Greening) Disease. Intemational Journal of Systematic Bacteriology 47: 224-227.

14. Mangold R.D. and Bonner F.T. 2008. Certification of Tree Seed and Other Woody Plant Material In: Bonner F.T. and Karrfalt R.P. (eds). The Woody Plant Seed Manual Agriculture Hand-Book 727. Chapter 6. USDA Forest Service. Washington.

15. Nyoka, B.I. 2011. Certification of Agroforestry Tree Germaplasm in Southern Africa: opportunities and challenges. Agroforest System. DOI 10.1007/s10457-011-9393-4

16. Purnomosidhi, P \& Roshetko, J.M. 2012. Legalitas Produksi Bibit Tanaman Hortikultura Dari Masyarakat. (Legality Of Smallholder Horticulture Seedling Production).

17. Falivene. S \& Creek, A. 2017. Citrus plant protection and management guide 2017. NSWDPI Management Guide. www.dpi.nsw.gov.au.

18. Subandiyah S. 2000. Comparison of $16 \mathrm{~S}$ RNA and $16 S 23 S$ intergenic region sequencesn an10ng citrus greening organisms in Asia. Plant Disease 84: 15-18.

19. Supriyanto, A. 1992. Citrus Rehabilitation in Indonesia. In Proc. 11th Conference of the International Organization of Citrus Virologists. Riverside, CA (pp. 409-413).

20. Supriyanto, A. (1992). The Indonesian Citrus Improvement Programme. In Proc. Asian Citrus Rehab. Conf. Puslitbang Hortikultura. (pp. 50-58).

21. Supriyanto, A. 2015a. Adopsi teknologi anjuran Produksi Bibit Jeruk Keprok SoE (Citrus reticulata Blanco) berlabel biru dalam polibag dalam Soemargono cs. In Prosiding Seminar Buah Tropika Nusantara II. (pp. 1167-1176).

22. Supriyanto A. 2015b. Potret and Upaya Industrialisasi Perbenihan Jeruk di Kawasan Bangkinang, Kabupaten Kampar, Riau Prosiding Seminar Nasional Perhorti 2015, Bogor.

23. Supriyanto, A, Ratule, MT \& Syakir, M. 2017. Citrus Variety Improvement Program In Indonesia: Varieties, Production And Distribution Viruses Free Of Citrus Nursery Stocks. International Symposium on Tropical Fruits Proc. Fiji. 